\title{
Effect of Oily Sludge Land Treatment on Soil Conditions
}

\author{
Hasan Mahdi M. Al-Khateeb
}

\begin{abstract}
Land treatment is a method of handling wastes produced by the petroleum refining industry and others. This method allows the simultaneous treatment and final disposal of the waste. This study represent a fundamental filed investigation to follow the land treatment method for disposing of an oily sludge produce by Daura Refinery Wastewater Treatment Plant. The sludge typically consists of (84.5-86.2) \% water, (4.7-5.3) \% oils, and (8.4-9.25) \% sediments. It is characterized by law contents of phenol, nitrogen, and heavy metals of environmental concern. Loamy sand soil land located inside Daura Refinery was selected and divided into a1-sq. meter plots. A range of sludge application rates was applied to add the sludge to (mix with) the upper $15 \mathrm{~cm}$ soil layer of 18 plots, whereas 6 plots left as control plots. The applications range included three applications ratios of (fresh sludge wt., dry soil wt.) as (1:3), (1:6), and (1:10), each of them was applied in three application intervals: weekly, monthly, and seasonally. Selection of the best application rate was made with regard to sludge degradation and land area requirements. Soil samples were tested for oil residue, heavy metals, total nitrogen, electrical conductivity, $\mathrm{pH}$, and aggregate stability. The results show that, monthly (1:10) application rate caused neither considerable downward oil migration in the soil nor significant accumulation of oil, heavy metals, or salts in the soil. However, it maintained neutral soil $\mathrm{pH}$ and improved soil aggregate stability. Oil biodegradation in the soil was encouraged by soil weakly tillage.
\end{abstract}

Index Terms —Land; Oily Sludge; Soil; Treatment.

\section{INTRODUCTION}

The oil refining industry is considered one of the most important industries, which produce significant amounts of pollutants and waste. Ultimate disposal of oily sludge has been a problem for years, and increasing pressure by environmental agencies has reduced disposal alternatives. Land treatment allows the simultaneous treatment and final disposal of the sludge. It is a managed treatment and an ultimate disposal process that involves repeated controlled application of oily or biological sludge to a given soil (or soil-vegetation system), and the promotion of naturally occurring microbial assimilation to convert hydrocarbons and organic matter to end products of $\mathrm{CO} 2, \mathrm{H} 2 \mathrm{O}$, and increased humus content of the soil [1], [2]. It is also named as land farming, land spreading, land application, sludge farming, soil cultivation and land disposal [3].

Land treatment is the designation officially recognized by the US Environmental Protection Agency [3]. In addition to petroleum refining industry, it has been used successfully for the treatment and disposal of other industrial waste such as wastes from the wood preserving, pulp and paper,

Publised on September 17, 2018.

H. M. M. Alkhateeb, the Civil Engineering Department, Faculty of Engineering, University of Kufa, P.O. Box (21), Kufa, Najaf, Iraq (e-mail: hasan.alkhateeb@uokufa.edu.iq). pharmaceutical, and food processing industries. Sewage and agricultural sludges have been also land treated [4], [5].

Land treatment of oily waste and sludges had been investigated since seventies of last century [6]-[8]. During the eighties and nineties, more detailed studies had been carried out to investigate optimal conditions for land treatment of oily sludge regarding decomposition rates and effect on plant [9],[10], potential movement of oil compounds in soil [11]-[13], loading rates [14]-[17], effect on run-off quality [18],[19]. After 2000, considerable research works directed towards factors influencing biodegradation of oily sludge and hydrocarbons in soil [20][28].

In Iraq, the sludge produced by Daura refinery Wastewater Treatment plant was used to be burned on specially imported heated sand by incinerator. The incinerator was found to have some practical problems during operations such as frequent clogging of filters, considerable losses in fluidized bed sand and combustion difficulties caused by high water content of the sludge and low dewatering efficiency. The main purpose of this study is to investigate the use of land treatment method as an alternative disposal for the sludge. Oil degradation in soil, and soil conditions changed by sludge land treatment were investigated in particular.

\section{MATERIALS AND METHODS}

\section{A. Materials}

A homogenous soil sample was prepared by collecting surface soil from a selected site inside Daura Refinery and spreaded over a $(27 \mathrm{~m} \times 8 \mathrm{~m})$ land area inside the refinery. The soil was classified as Typic torrifulvent and its texture was loamy sand. Some physical and chemical properties of the soil were determined as shown in Table I. Soil bulk density was determined by Core method, and particle size distribution by the hydrometer method after sieving [29]. Electrical conductivity (EC) was measured in (1:2) water extract while $\mathrm{pH}$ was measured in (1:2.5), [30]. The soil had low total nitrogen content $(0.01 \%)$ and slightly alkaline $\mathrm{pH}$ (7.41). The land was leveled and divided into 24 plots of one square meter each distributed on one-meter spacing and each of them surrounded by $10 \mathrm{~cm}$ height bricks to be isolated from the others.

\begin{tabular}{cc} 
TABLE I: DETERMINED CHARACTERISTICS OF THE SOIL USED. \\
\hline \hline Characteristic & Results \\
\hline Sand & $84.6 \%$ \\
Silt & $4.5 \%$ \\
Clay & $10.8 \%$ \\
Soil texture & loamy sand \\
Bulk density & $1.35 \mathrm{~g} / \mathrm{cm} 3$ \\
pH & 7.41 \\
Electric conductivity (ECe) at $25^{\circ} \mathrm{C}$ & 1.56, \\
Total nitrogen & $\mathrm{mS} / \mathrm{cm}$ \\
\hline \hline
\end{tabular}


Constant irrigation of (40 liters) raw water by two-day intervals was followed to irrigate each plot throughout the experiments of this study. It was found (by field trail runs) to keep soil moisture above $10 \%$. Water used for irrigation was supplied from raw water network of the refinery which drawn water from the Tigris river.

Sludge used in this study was taken from Sludge Thickening Tank of Wastewater Treatment plant of Daura Refinery which consist of two stages of API separator (floatation), coagulation, dissolved air floatation, aeration, clarification and disinfection. The sludge was periodically analyzed as shown in Table II.

TABLE II: CHARACTERISTICS OF THE END SLUDGE PRODUCT OF DAURA REFINERY WASTEWATER TREATMENT PLANT USED IN THE STUDY.

\begin{tabular}{lll}
\hline \hline Characteristic & Range & Unit \\
\hline Density at $35^{\circ} \mathrm{C}$ & $1.0004-1.015$ & $\mathrm{~g} / \mathrm{cm} 3$ \\
Electrical conductivity at $25^{\circ} \mathrm{C}$ & $2.75-3.66$ & $\mathrm{mS} / \mathrm{cm}$ \\
$\mathrm{pH}$ & $8.0-8.5$ & \\
Water & $84.5-86.2$ & $\%$ \\
Oil & $4.7-5.3$ & $\%$ \\
Residue & $8.4-9.25$ & $\%$ \\
Ash & $3.15-3.6$ & $\%$ \\
Total Nitrogen & $0.10-0.14$ & $\%$ \\
Phenol & $0.026-0.29$ & $\mathrm{ppm}$ \\
Cadmium & $1.3-1.9$ & $\mathrm{ppm}$ \\
Chromium & $3.9-27.4$ & $\mathrm{ppm}$ \\
Copper & $5.2-37.6$ & $\mathrm{ppm}$ \\
Nickel & $7.6-41.8$ & $\mathrm{ppm}$ \\
Lead & $6.1-7.6$ & $\mathrm{ppm}$ \\
Zinc & $107.5-183.5$ & $\mathrm{ppm}$ \\
\hline \hline
\end{tabular}

\section{B. Methods}

Sludge mixing with upper $15 \mathrm{~cm}$ soil layer continued during four months according to different sludge application rates. Application rates had two variables. The first was sludge application ratio, using three (wt./wt.) ratios (1:3), (1:6), and (1:10) as sludge fresh weight: soil dry weight). The second was sludge application intervals, using three intervals as weekly, monthly, and seasonal (4 months). Other factor was tillage of the upper $15 \mathrm{~cm}$ soil that mixed with the sludge. So, nine plots were used for the three ratios and the three application intervals, and other nine corresponding plots having similar sludge application ratios and intervals were subjected to weekly tillage. Totally, 18 plots were used to cover the three independent factors (application ratio, application intervals, and tillage) beside six control plots. The sludge quantitated by a balance, applied by buckets, and mixed with the soil using manual shovel. The weekly soil tillage was, also, made by shovel.

Soil sampling for all soil tests was carried out by collecting three separate random soil samples from each plot being tested. The three samples (of each plot) were well mixed to give one representative soil samples for the plot. Some of important soil characteristics that were expected to be effected by sludge application were checked after the four months passed. Soil $\mathrm{pH}$ was measured in (1:2.5) water extract [30]. Heavy metals that were originally included by the applied sludge $(\mathrm{Cd}, \mathrm{Cr}, \mathrm{Cu}, \mathrm{Pb}$, and $\mathrm{Zn})$ were checked with respect to permissible limits keeping plant and animal health. Total heavy metal extraction was carried out by strong acids (HNO3- $\mathrm{HCIO} 4, \mathrm{HNO} 3-\mathrm{H} 2 \mathrm{SO} 4$, or $\mathrm{HCl}-$ HNO3), and measured by Atomic Absorption Spectrophotometry [31]. Soil salinity by means of Electrical conductivity (ECe) index was measured in (1:2) water extract [30]. Total nitrogen content was measured according to Kjeldahl disgestion method [29]. Aggregate stability indicated by measuring soil Mean Weight Diameter (M.W.D) by wet sieving process using Yoder machine [29]. Oil content of soil samples was measured gravimetrically for soil extracted by Bezen (BDH), [32].

Oil downward movement was indicated by measuring oil content for soil samples of $25-30 \mathrm{~cm}$ depth. Oil degradation with soil tillage effects was checked by the difference in oil content of soil samples of $0-15 \mathrm{~cm}$ depth taken after the first seasonal sludge application by one day and four months, respectively. For the same plots and depth, soil samples were tested for total microbial content before (by two days) and after (by four months) of the seasonal sludge application according to pouring plate Count method [33].

\section{RESUlTS AND DISCUSSION}

During the four months of the successive sludge application, different sludge quantities were applied to the plots according to the different comprised application rates (treatments). Table III lists total sludge quantities applied through the four months. The different treatments had different effect levels on soil conditions and characteristics. Table IV lists test results of M.W.D, pH, total nitrogen, ECe, and oil content at a $(25-30 \mathrm{~cm}$ depth of oil downward migration).

\section{A. Oil downward movement}

Considering third column of Table IV, it can be distinguished that considerable oil contents were observed at the weekly treated plots, indicating considerable oil downward movement. Also, a rather considerable oil movement can be deducted in the plots treated by the monthly (1:3) and (1:6) treatments, whereas no obvious oil movement can be noticed in the plots of the seasonal treatments, as well as, in the monthly $(1: 10)$ treatment relative to the control plot. High oily sludge application rates made the excessively applied oil move downward in soil by gravity or with the aid of irrigation water through infiltration causing oil downward migration. In low oily sludge application rates, most of the applied oil could be retained (adsorbed) in soil mixing zone (the upper $15 \mathrm{~cm}$ layer), indicating no obvious oil movement.

TABLE III: TOTAL SLUDGE QUANTITIES APPLIED TO THE PLOTS ACCORDING TO DIFFERENT RATES (ALONG FOUR MONTHS OF CONTINUOUS SLUDGE

\begin{tabular}{|c|c|c|c|c|}
\hline $\begin{array}{l}\text { Sludge: Soil } \\
\text { application } \\
\text { ratio }\end{array}$ & $\begin{array}{l}\text { Sludge } \\
\text { application } \\
\text { intervals }\end{array}$ & $\begin{array}{c}\text { Sludge } \\
\text { quantity of } \\
\text { each one } \\
\text { application, } \\
\text { kg }\end{array}$ & $\begin{array}{c}\text { No. of } \\
\text { sludge } \\
\text { applications } \\
\text { along four } \\
\text { months }\end{array}$ & $\begin{array}{c}\text { Total } \\
\text { applied } \\
\text { sludge, } \\
\text { kg }\end{array}$ \\
\hline $1: 3$ & Weekly & 33 & 14 & 462 \\
\hline $1: 6$ & Weekly & 17 & 14 & 238 \\
\hline $1: 10$ & Weekly & 10 & 14 & 140 \\
\hline $1: 3$ & Monthly & 33 & 4 & 132 \\
\hline $1: 6$ & Monthly & 17 & 4 & 68 \\
\hline $1: 10$ & Monthly & 10 & 4 & 40 \\
\hline $1: 3$ & Seasonal & 33 & 1 & 33 \\
\hline $1: 6$ & Seasonal & 17 & 1 & 17 \\
\hline $1: 10$ & Seasonal & 10 & 1 & 10 \\
\hline
\end{tabular}


TABLE IV: SOME OF SOIL CHARACTERISTICS CHECKED FOR THE PLOTS TREATED BY DIFFERENT OILY SLUDGE APPLICATION RATES AT THE END OF FOUR MONTHS OF CONTINUOUS SLUDGE APPLICATION.

\begin{tabular}{|c|c|c|c|c|c|c|}
\hline $\begin{array}{l}\text { Sludge: } \\
\text { soil } \\
\text { applicatio } \\
\text { n ratio }\end{array}$ & $\begin{array}{c}\text { Sludge } \\
\text { applicatio } \\
\mathrm{n} \\
\text { intervals }\end{array}$ & $\begin{array}{c}\text { Oil } \\
\text { Conten } \\
\mathrm{t} \% \text { at } \\
(25-30) \\
\mathrm{cm} \\
\text { depth }\end{array}$ & $\mathrm{pH}$ & $\begin{array}{c}\text { Total } \\
\text { Nitroge } \\
n \\
(\% \mathrm{~N})\end{array}$ & $\begin{array}{c}\mathrm{EC} \\
(\mathrm{mS} / \mathrm{c} \\
\mathrm{m})\end{array}$ & $\begin{array}{c}\text { MW } \\
\text { D } \\
(\mathrm{mm} \\
)\end{array}$ \\
\hline $1: 3$ & Weekly & 2.602 & 7.82 & 0.28 & 4.16 & 3.62 \\
\hline $1: 6$ & Weekly & 0.964 & 7.66 & 0.19 & 3.07 & 13 \\
\hline $1: 10$ & Weekly & 0.384 & 7.47 & 0.12 & 2.36 & 2.66 \\
\hline $1: 3$ & Monthly & 0.153 & 7.51 & 0.09 & 2.19 & 2.84 \\
\hline $1: 6$ & Monthly & 0.091 & 7.44 & 0.06 & 1.83 & 1.28 \\
\hline $1: 10$ & Monthly & 0.01 & 7.41 & 0.04 & 1.66 & 1.05 \\
\hline $1: 3$ & Seasonal & 0.009 & 7.41 & 0.02 & 1.64 & 1.13 \\
\hline $1: 6$ & Seasonal & 0.012 & 7.42 & 0.01 & 1.61 & 3.62 \\
\hline $1: 10$ & Seasonal & 0.008 & 7.41 & 0.01 & 1.62 & 0.25 \\
\hline Control & None & 0.006 & 7.42 & 0.01 & 1.58 & 0.22 \\
\hline
\end{tabular}

\section{B. Oil degradation with tillage effect}

Oil degradation in the soil studied for the seasonal treated plots to permit more time for degradation. Very restricted oil downward migration was observed in seasonal treatments; hence, most of the applied oil was under degradation action at the upper $15 \mathrm{~cm}$ layer. Soil tillage was independent factor affecting oil degradation beside sludge application rate. Table V lists results of oil content tests obtained for soil samples (of 0-15 cm depth) taken from weekly tilled and corresponding none tilled plots. The results show that, degradation ratio increased with decreasing application ratio, and soil tillage enhanced oil degradation. This observation can be explained in terms of microbial population found in the soil responsible for oil biodegradation. Soil microbial mass multiplication (growth) may be as an indicator of oil biodegradation because the major products of oil aerobic biodegradation are $\mathrm{H} 2 \mathrm{O}, \mathrm{CO} 2$, and new microbial cell [4], [34]. Table VI lists the results of soil total microbial count before and after the four months of the seasonal oily sludge application, and microbial growth. Soil tillage enhance soil aeration which, in turn, increase oil degradation because aerobic biodegradation is much more rapid and complete than anaerobic. In addition, soil tillage improves physical dilution and uniform distribution of oil in soil to have a better contact between oil and soil microorganisms, which break down the oil, resulting in increasing oil biodegradation [4], [35].

TABLE V: SOIL TILLAGE EFFECTS ON OIL DEGRADATION IN PLOTS SEASONALLY TREATED WITH OILY SLUDGE (SOIL SAMPLES FOR UPPER 15 CM LAYER).

\begin{tabular}{|c|c|c|c|c|c|}
\hline $\begin{array}{l}\text { Sludge } \\
\text { application } \\
\text { ratio }\end{array}$ & Tillage & $\begin{array}{l}\% \text { oil cor } \\
\text { upper } 1 \\
\text { layer af } \\
\text { applica } \\
1 \text { day }\end{array}$ & $\begin{array}{l}\text { tent in the } \\
5 \mathrm{~cm} \text { soil } \\
\text { er sludge } \\
\text { ion by: - } \\
4 \text { months }\end{array}$ & $\begin{array}{c}\text { Difference* }^{*} \\
\%\end{array}$ & $\begin{array}{l}\text { Oil degradation } \\
\text { ratio } * * \\
\%\end{array}$ \\
\hline $1: 3$ & none & 1.650 & 0.420 & 1.230 & 74.5 \\
\hline $1: 6$ & none & 0.800 & 0.160 & 0.640 & 80 \\
\hline $1: 10$ & none & 0.530 & 0.075 & 0.445 & 85.9 \\
\hline $1: 3$ & tilled & 1.580 & 0.160 & 1.420 & 89.9 \\
\hline $1: 6$ & tilled & 0.880 & 0.070 & 0.810 & 92.1 \\
\hline $1: 10$ & tilled & 0.470 & 0.020 & 0.450 & 95.7 \\
\hline control & none & 0.007 & 0.009 & $\simeq 0.000$ & -- \\
\hline \multicolumn{6}{|c|}{$\begin{array}{l}* \text { Difference }(\text { degraded oil })=\text { oil content of }(1 \text { day }-4 \text { months }) \\
* * \text { Oil degradation ratio }=(\text { difference in oil content } / \text { oil content of } 1 \\
\text { day }) * 100 \%\end{array}$} \\
\hline
\end{tabular}

It may be worth mentioning that, all of the obtained oil degradation ratios were relatively high. That may due to relatively low oil content $(5 \%)$ and presence of acclimated microbial populations in the sludge used (provided from the biological treatments unit of the Wastewater Treatments Plant of the Refinery).

Combined effects of both soil tillage and decreasing sludge application ratio made the (1:10) tilled treatments the best one according to oil degradation ratio. It has greatest $(95.7 \%)$ oil degradation ratio. Accordingly, the monthly (1:10) treatments has the highest oil degradation ratio relative to the other monthly and weekly treatments.

TABLE VI: EFFECT OF SOIL TILLAGE ON SOIL MICROBIAL GROWTH IN THE PLOTS TREATED BY THE OILY SLUDGE ACCORDING TO THE SEASONAL

\begin{tabular}{|c|c|c|c|c|c|}
\hline $\begin{array}{c}1 \\
\text { Sludge } \\
\text { application } \\
\text { ratio } \\
\text { Sludge:Soil }\end{array}$ & $\begin{array}{c}\text { Weekly } \\
\text { tilling }\end{array}$ & $\begin{array}{c}3 \\
X 10^{2} \text { Initial } \\
\text { count(a) per } \\
1 \text { gm soil }\end{array}$ & $\begin{array}{c}4 \\
X 10^{5} \\
\text { Final } \\
\text { count(b) } \\
\text { per } \\
1 \text { gm soil } \\
\end{array}$ & $\begin{array}{c}5 \\
\text { X } 10^{5} \\
\text { Difference(c) } \\
\text { per } \\
1 \text { gm soil }\end{array}$ & $\begin{array}{c}6 \\
\text { X } 10^{2} \\
\text { Microbial } \\
\text { Mass(d) } \\
\text { Multiplication }\end{array}$ \\
\hline $1: 3$ & none & 38 & 59 & 58.962 & 15.52 \\
\hline $1: 6$ & none & $40: 3$ & 47 & 46.960 & 11.65 \\
\hline $1: 10$ & none & 40.7 & 39.7 & 39.659 & 9.74 \\
\hline $1: 3$ & tilled & 47.3 & 94 & 93.953 & 19.86 \\
\hline $1: 6$ & tilled & $42.5^{*}$ & 78.3 & 78.258 & 18.41 \\
\hline $1: 10$ & tilled & $44.5^{*}$ & 75 & 74.956 & 16.84 \\
\hline Control & none & $43.5^{*}$ & 0.062 & 0.0185 & 0.004 \\
\hline
\end{tabular}

(a): Before sludge application to soil by two days (average of three replications).

(b): After four months from sludge application to soil (average of three replications).

(c): Column $5=$ column $4-$ column 3

(d): Column $6=$ column $5 \div$ column 3

*: Average of two replications.

\section{Soil pH}

The fourth column of Table III gives $\mathrm{pH}$ tests results of the treated plots and the control plot. Generally, the overall measured $\mathrm{pH}$ range was (7.41-7.82). This range is within the optimal $\mathrm{pH}$ range (6.5-8.0) for microbial activity as well as for the formation of insoluble precipitates, and it results in the immobilization of certain heavy metals [4]. As application rate increased, $\mathrm{pH}$ increased slightly, too. This may due to alkalinity of the sludge that overcome soil buffer capacity.

\section{Heavy metals}

Table VII lists total content of the measured heavy metals $(\mathrm{Cd}, \mathrm{Cr}, \mathrm{Cu}, \mathrm{Ni}, \mathrm{Pb}$ and $\mathrm{Zn}$ ) in soil of two treated plots 1 and 6 and the control plot 11. Table VII lists also, tolerable total content of the metals in soil with regard to the health of vegetables, livestock, and man. Generally, soil heavy metal increased with increasing application rate. However, their contents in the treated soil with the monthly (1:10) treatments were far below the tolerable total contents. Keeping soil $\mathrm{pH}$ above 6.5 results in metal immobilization due to precipitation as carbonates, hydroxides, phosphates, etc. [36]. Soil $\mathrm{pH}$ of the plot monthly treated was 7.41 (Table IV). Thus, this treatment is expected to enable innocuous and sludge application regarding heavy metal content of the treated soil. 


\section{E. Soil salinity by Electrical conductivity (ECe) index}

Sixth column of Table IV shows that the ECe of all treated plots is higher than that of the control one, and the increase in ECe is proportional to sludge application ratio and is inversely related with the application intervals. This may be due to the presence of soluble salts included in the applied sludge, particularly because EC of the sludge was (2.58-3.66 mS/cm) (Table II). The U.S. Salinity Laboratory Staff [38] proposed a classification of saline soils with respect to the expected salt damage to croups depending on the ECe into; non-saline, moderately saline, very saline, and extremely saline soils. This classification is illustrated in Table VIII. It can be noticed that most of the treated soils did not meet an effective saline range $(>4 \mathrm{mS} / \mathrm{cm})$, especially, those of seasonal and monthly (1:10) treatments which had a slight preponderance in ECe of (0.03-0.08 $\mathrm{mS} / \mathrm{cm}$ ) relative to the control plot.

TABLE VII: TOTAL CONTENT OF SOME HEAVY METALS IN SOIL OF SELECTED PLOTS TREATED* BY DIFFERENT OILY SLUDGE APPLICATION RATES, WITH SOIL TOLERABLE CONTENTS OF THE METALS. (ALL IN MG/KG

\begin{tabular}{ccccc}
\multicolumn{5}{c}{ AIR-DRIED SOIL). } \\
\hline \hline $\begin{array}{c}\text { Plot no. } \\
\text { (sludege: soil) }\end{array}$ & 1 & 6 & 11 & \\
$\begin{array}{c}\text { appl. ratio } \\
\text { Sludge application }\end{array}$ & $(1: 3)$ & $(1: 10)$ & Control & $\begin{array}{c}\text { Tolerable total } \\
\text { content in soil** } \\
\text { intervals }\end{array}$ \\
$\begin{array}{c}\text { [37] } \\
\text { Total no. of sludge } \\
\text { appls. }\end{array}$ & 14 & 4 & 0 & \\
\hline Heavy metal & \multicolumn{5}{c}{ total content $(\mathrm{ppm})$} \\
\hline Cadmium $(\mathrm{Cd})$ & 4.7 & 0.17 & 0.24 & 5 \\
Chromium $(\mathrm{Cr})$ & 95.3 & 16.73 & 14.17 & 100 \\
Copper $(\mathrm{Cu})$ & 146.5 & 30.14 & 25.94 & 100 \\
Nickel $(\mathrm{Ni})$ & 93.6 & 14.52 & 11.88 & 50 \\
Lead $(\mathrm{Pb})$ & 58.5 & 9.07 & 9.25 & 100 \\
Zinc $(\mathrm{Zn})$ & 321.8 & 54.86 & 23.65 & 300 \\
\hline \hline
\end{tabular}

(*) After four months of continuous sludge application.

(**) With regard to the health of vegetables, livestock, and man.

TABLE VIII: EXPECTED SALT EFFECT ON CROP GROWTH, AS A FUNCTION OF THE CONCENTRATION IN THE SATURATION EXTRACT [30], [38]

\begin{tabular}{ccc}
\hline $\begin{array}{c}\text { Range of } \\
\text { Ece* } \\
(\mathrm{mS} / \mathrm{cm})\end{array}$ & $\begin{array}{c}\text { Effect } \\
\text { on plant }\end{array}$ & $\begin{array}{c}\text { Proposed } \\
\text { classification }\end{array}$ \\
\hline $0-2$ & $\begin{array}{c}\text { Salinity } \\
\text { effects mostly negligible } \\
2-4\end{array}$ & $\begin{array}{c}\text { Yields of very sensitive croups } \\
\text { restricted }\end{array}$ \\
$4-8$ & $\begin{array}{c}\text { Yields of many croups restricted } \\
\text { Only tolerant croups yield } \\
\text { satisfactory }\end{array}$ & $\begin{array}{c}\text { Slightly saline } \\
\text { Moderately saline }\end{array}$ \\
$>16$ & $\begin{array}{r}\text { Only a few very tolerant croups } \\
\text { yield satisfactorily }\end{array}$ & Extremely saline \\
\hline \hline
\end{tabular}

\section{F. Total Nitrogen content}

Considering fifth column of Table IV, it can be concluding that soil total nitrogen content increased with increasing sludge application rate (increasing sludge application ratio and decreasing is intervals). This may be attributed to the nitrogen contained by the applied sludge, Table II. Presumably, the increased nitrogen content is, also, due to microbial cells accumulation and/or microbial metabolism by-products of oil biodegradation.

\section{G. Soil aggregate stability as shown by Mean Wight Diameter $(M W D)$ index}

The third column of Table IV illustrates the measured Mean Weight Diameter MWD for soil samples of the treated soil plots and the control plot. It is obvious that sludge application caused a diametric increasing in the MWD of soil aggregate, especially, of the weekly and the monthly treated plots. The increase in MWD means increasing soil aggregate size, which is caused by the added organic matter, mainly oil, included by the applied oily sludge. Soil particles might be agglomerated with the aid of this organic matter. In addition, oil hydrophobic nature retards water penetration during the wet sieving (of MWD test) and prevents soil destruction. Many works also reported that poor wettability and water repellency can be caused by microbial growth in the soil which might give higher values for aggregate stability indices [39],[40]. In weekly (1:3) treatments, intensive sludge application may disperse some of soil aggregates, causing a reduction in the MWD in comparison to that of the weekly $(1: 6)$ treatments. Generally, the increase in the MWD improves soil conditions like aeration and erosion resistivity. Although soil aggregates were stabilized largely through the weekly treatments, the excess sludge levels developed in the soil may have adverse environmental effects such as phytotoxisity, water pollution potential, and soil wettability reduction.

\section{CONCLUSIONS}

Based on the results obtained by this study, monthly sludge application according to $(1: 10)$ (fresh sludge wt: dry soil wt.) (i.e., 201 of fresh sludge $/ \mathrm{m} 2$ ) is the best application rate among the other ratios studied. It lade to proper oil degradation rate $(85.9-95.7 \%$ applied oil $/ 4$ months) with no considerable downward oil movement, heavy metals accumulation, $\mathrm{pH}$ change, and salinity buildup in the treated soil. It resulted in an appreciable increase in soil total nitrogen (from 0.01 to $0.04 \%$ ) content and remarkable improvement in soil aggregate stability (MWD improved from 0.22 to $1.05 \mathrm{~mm}$ ). Weekly soil tillage increased oil degradation effectively.

\section{ACKNOWLEDGMENT}

The Directorate of Studies, Planning and Follow-up of Iraqi Ministry of Oil supported this work. The Directorate allowed the investigation to be carried out in Daura Refinery and facilitate the work by providing different facilitate, like laboratories, related information, workers, equipment, and financial support.

\section{REFERENCES}

[1] Grove, G.W. "Use landfarming for oily waste disposal". Hydrocarbon Processing, 57: 138-140, 1978.

[2] Raymond. C.L.; ASCE, M.; and Overcash, M.R., "Land Treatment of Wastes: Concepts and general design", J. Environ. Engineering, 111(2): 141-160, 1985.

[3] Handdelston, R.L. "Solid waste disposal: Landfarming", Chemical Engineering, 86(5): 119-124, 1979.

[4] Arora, H.S.; Cantor, R.R.; and Nemeth, J.C., "Land treatment: Available and successful method petroleum industry wastes", Environ International., 7: 285-291, 1982.

[5] Raymond, C.L.; John, R.R.; and Rucker, J.E. " Land Treatment is viable technology for reducing petroleum - waste toxicity and migration potential", Oil \& Gas J., 85(44): 40-43, 1987.

[6] Dotson, G.K.; Dean, R.B.; Kenner, B.A.; and cooke, W.E. "Land spreading: A conversation and Non- polluting method of disposing of 
oily wastes", 5th Intl. Water Poll. Res. Conf. and Exhib., San Francisco, CA, July 26 - Aug 1,1970. (Cited in El-Nawawy 1990).

[7] Kincannon, C.B. "Oily waste disposal by soil cultivation process", U.S. Govt. publication, EPA-P-72-110, Washington D.C. U.S.A.,1972. (Cited in El-Nawawy, 1990).

[8] Dibble, J.T. and Bartha, R. "Effect of environmental parameters on the biodegradation of oily sludge", Appl. Environ. Microbiol., 37(4): 729-739, 1979 .

[9] Brown, K.W.; Barwand H.; Thomas J.C.; and Evans, G.B. "Impact of simulated land treatment with oily sludges on reyegrass emergence and yield". Agronomy J. 74 (2): 257-261, 1982.

[10] Wilton, B.S.; Bloys, J.B.; Watts, R.D.; and Hipp, B.W., "Drilling wastes evaluated in plant growth study", Drilling proceedings - SPE Annual Technical Conference and Exhibition, Washington, DC. USA 1992, Oct. 4-7, 1992.

[11] Brown, K.W. and Deuel, Jr. L.E., "Evaluation of subsurface conditions at refinery land treatment sites", Texas A and M Univ., College station, USA, Report no.: EPA - 600/2 - 83- 096, 1983.

[12] Bleckmann, C.A.; Gawel L.J.; Whitfill, D.L.; and Swindoll, C.M (1989) "Land Treatment of Oil - based drill cuttings", SPE/IADC 1989 Drilling. Conference, New Orleans, L.A., USA, Feb. 28 - Mar 3, 1989

[13] El-Bagouri, I.H.; El-Nawawy, A.S.; Abdal, M.; Al-Daher, R.; Khalafawi M.S.; Whitton, B.A.; and Wong. Ming H. (eds) "Mobility of oil and other sludge constitute during oily sludge treatment by landfarming", Int. Conf. of Environmental Biotechnology in Waste Treatment and Recycling, Hong Kong, Jan. 12-14, 1994.

[14] Streebin, L.E.; Robertson, J.M.; Schornick, H.M; Bowen, P.T.; and Bagawandoss, K.M. "Land Treatment of Petroleum Refinery Sludges", Oklahoma Univ., Norman School of Civil Eng. And Environ. Sci., Report no. EPA/600/2-84/193, 1984.

[15] Streebin, L.E.; Robertson, J.M.; Callender, A.B.; Doty, L.; and Bagawandoss, K., "Closure evaluation for petroleum residue land treatment", Oklahoma U niv., Norman School of Civil Eng. And Environ. Sci., Report no. EPA/600/2-84/162, 1984.

[16] Genouw G, Naeyer F, Meenen P, Werf H, Nijs W, "Degradation of oily sludge by land farming - a case study at the Ghent Harbour". Biodegradation 5: 37-46,1994.

[17] Al-Khateeb, H.M, "Disposal of an Oily Sludge by Landfarming", M.Sc. thesis, Civil Engineering Dep., College of Engineering, University of Mustansiriya, Baghdad, Iraq,1997.

[18] Overcash, M.R.; Nutter, W.L.; Kendall, R.L.; and Wallace, J.R. "Field and laboratory evaluation of petroleum land treatment system closure". Earth system associates, Material, GA. Report no. EPA/600 2-85-134, 1985.

[19] Prado-Jatar M, Correa M, Rodriguez-Graw J, Carneiro M, "Oily sludge land farming biodegradation experiment conducted at a tropical site in eastern Venezuela". Waste Management and Research 11: 97-106, 1993.

[20] Mishra S., J. Jyot, R. C. Kuhad and B. Lal, "Evaluation of Inoculum Addition to Stimulate in Situ Bioremediation of Oily Sludge Contaminated Soil", Appl. Environ. Microbial., 67, 1675-1681, 2001.

[21] Del'Arco JP, de Franca FP "Influence of oil contamination levels on hydrocarbon biodegradation in sandy sediments", Environ. Pollut. 112:515-519, 2001

[22] Zucchi M, Anghoni L, Borin S, Brusetti L, Dietrich G, "Response of bacterial community during bioremediation of an oil polluted soil". $J$ Appl Microbiol , 94: 248-257, 2003

[23] Hejazi RF, Husain T, Khan FI, "Landfarming operation of oil sludge in arid region-human health risk assessment", J. Hazard. Materi. B99:287-302, 2003.

[24] Mehrashi MR, Haghighi B, Shariat M, Naseri S, Naddafi K "Biodegradation of petroleum hydrocarbon in soil". Iran. J. public Health. 32 (3):28-32, 2003.

[25] Christopher W, Kaplan, Christopher L, Kitts "Bacterial succession in a petroleum land treatment unit". Appl Environ Microbiol, 70: 17771786, 2004.
[26] Radetski CM, Mater L, Sperb RM, Madureira LAS, Rosin AP, Correa AXR, "Proposal of a sequential treatment methodology for the safe reuse of oil sludge-contaminated soil". J. Hazard. Mat. B ,136:967971, 2006.

[27] Crivelaro SHR, Mariano AP, Furlan LT, Gonçalves RA, Seabra PN, Angelis DF "Evaluation of the use of vinasse as a biostimulation agent for the biodegradation of oily sludge in soil". Int. J. Brazil Biol Technol. 53(5):1217-1224, 2010.

[28] Liu W, Luo Y, Teng Y, Li Z, Ma L Q. "Bioremediation of oily sludge-contaminated soil by stimulating indigenous microbes". Environ Geochem Health. 32:23-29, 2010.

[29] Black, C.A., "Methods of Soil Analysis, Part 1", American Soc. Of Agronomy, Inc., Madison, Wisconsin, USA, 1965.

[30] United States Salinity Laboratory Staff, "Diagnosis and improvement of saline and alkali soils", Handbook 60. U.S. Govt. Printing Office, Washington, DC., USA, 1954.

[31] Black, C.A., "Methods of Soil Analysis, Part 2", American Soc. Of Agronomy, Inc., Madison, Wisconsin, USA. 1965

[32] Raymond, R.L.; Hudson. J.O; and Jamison, V.W.,"Oil degradation in soil", Apple Environ Microbiol., 31 (41):522-535, 1976

[33] Cappuccino, J.G. and Sherman, N. "Microbiology a laboratory manual", 2nd ed. Benjamin / Cumming Publishing Co. Inc. California USA pp. 303, 1987.

[34] Amaral, S.P. " Lanfarming of oily wastes: Design and Operation", Wat. Sci. Tech., 19 (8): 75-86, 1987.

[35] Mitchell, W.W.; Loynachan, T.E.; and Mckendrick, J.D. "Effect of tillage and fertilization on persistence of crude oil contamination in an Alaskan soil", J. Environ. Qual., 8(4): 525-532, 1979.

[36] United States Environmental Protection Agency, "Process design manual: Land application of municipal sludge", EPA - 625/1-83-016, USEPA. Center for Envion. Res. Information, Cincinnati, OH, USA 1983

[37] El-Nawawy, A.S., "Landfarming of oily sludge: an overview". Industerial Cooperation in The Arabian Gulf, (40): 29-46, 1990.

[38] Bolt, G.H. and Bruggenwert, M.G.M.; ed. "soil chemistry, A. Basic Elements", Elsevier Scientific Publishing Co., Amsterdam, the Netherlands, 1976, Pp. 173-174.

[39] Ellis, R. and Adams, R.S. "Contaminations of soils by petroleum hydrocarbons". Adv. Agron., 13: 197-216, 1961

[40] Al-Khafaji, A.A.; Asker, R.S.; and Kasal, S.M. " Effects of fuel oil on aggregate stability of a poorly structured soil form Dalmaj project", $J$. Agric. Water Reso. Res., 4 (2): 83-96, 1985.

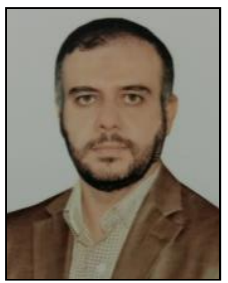

Assist. Prof. Dr. Hasan Mahdi M. Alkhateeb Born in Najaf Ashraf-Iraq in 1971 and awarded B.Sc. in civil engineering in 1994 from College of Engineering, University of Mustansiriya in Baghdad, Iraq. The same University awarded Alkhateeb the M.Sc. in environmental engineering in 1997 and Ph.D. in Environmental Engineering in 2002.

He designed a lot of water supply and sewerage projects for Iraqi cities including sewerage networks pump stations and treatment plants. He prepared so many environmental assessment studies for a verity of industrial and services projects. He is now a faculty member at the Civil Engineering Department, Faculty of Engineering- University of Kufa, Iraq. He was the vice dean and acting dean of the Faculty of Engineering in University of Kufa for eight years. His published research articles were in the field of environmental engineering like preliminary and biological wastewater treatment, performance and hydraulics of pump stations, groynes and other hydraulic structurs.

Assist. Prof. Dr. Hasan Alkhateeb is consultant member of Environment Protection and Improvement Council in Najaf Ashraf Province, Iraq since 2004. He is a member of the scientific committee of the Civil Engineering Dep, University of Kufa. 